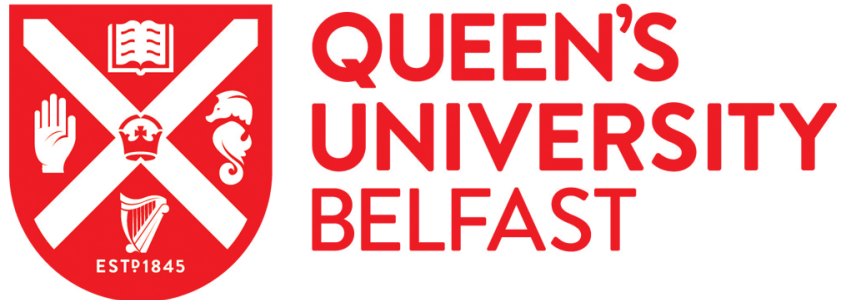

\section{'Victims of' human rights abuses in transitional justice: Hierarchies, perpetrators and the struggle for peace}

Hearty, K. (2018). 'Victims of' human rights abuses in transitional justice: Hierarchies, perpetrators and the struggle for peace. The International Journal of Human Rights. https://doi.org/10.1080/13642987.2018.1485656

\section{Published in:}

The International Journal of Human Rights

\section{Document Version:}

Peer reviewed version

Queen's University Belfast - Research Portal:

Link to publication record in Queen's University Belfast Research Portal

Publisher rights

(C) 2018 Informa UK Limited, trading as Taylor \& Francis Group.

This work is made available online in accordance with the publisher's policies. Please refer to any applicable terms of use of the publisher.

\section{General rights}

Copyright for the publications made accessible via the Queen's University Belfast Research Portal is retained by the author(s) and / or other copyright owners and it is a condition of accessing these publications that users recognise and abide by the legal requirements associated with these rights.

Take down policy

The Research Portal is Queen's institutional repository that provides access to Queen's research output. Every effort has been made to ensure that content in the Research Portal does not infringe any person's rights, or applicable UK laws. If you discover content in the Research Portal that you believe breaches copyright or violates any law, please contact openaccess@qub.ac.uk. 


\section{'Victims of' Human Rights Abuses in Transitional Justice: Hierarchies, Perpetrators and the Struggle for Peace}

\section{Introduction}

Transitional justice is suffused with victims' rights discourses. The right 'right to justice', the 'right to reparations' and the 'right to truth' are widely accepted as central pillars of transitional justice ${ }^{1}$ scholarship, policy and practice. ${ }^{2}$ For some, victims are now said to be 'a primary subject of the transitional justice enterprise' as participants, advocates and rights holders. ${ }^{3}$ Indeed, the victim has become integral to the self-legitimation of transitional processes, mechanisms and actors - why we do what we do. ${ }^{4}$ For all this, transitional justice processes must firstly determine who counts as a victim. This calculation of who is, or conversely is not, a victim in transitioning societies is at once a legal, political and technical one. In effect, this means that victims do not merely exist but rather they are 'produced' through intersecting political, legal and social processes. ${ }^{5}$ Politicised binaries are therefore drawn amongst and between victims, with highly legal criteria often used to differentiate between 'official victims' and 'unofficial victims'. ${ }^{6}$ In turn, this creates further friction between 'good' victims who acquiesce with this production process and 'bad' victims who challenge or resist it." Further division naturally arises through the diversity of the victim constituencies in terms of needs, interests and agendas. Here, fault lines like gender, class and ideology also interact with and are sometimes obscured by technical and political categorisations of victims. ${ }^{8}$ Accordingly, when transitional justice discourses and processes present themselves as being of and for 'the victims', such claims underplay the political and legal contests amongst victim constituencies. ${ }^{9}$ On this basis, one might legitimately ask whether the victim centeredness involves all victims or only some victims, and if the latter, what, and who, is it that determines which victims will be included and which victims will be excluded.

In response to these questions, this article explores a number of key divisions amongst victims in transitional justice. I argue that that these divisions hinge on the greater importance attached to the notion of being a victim of a number of key variables including; being a victim of a particular perpetrator, being a victim of a particular harm and being a victim of circumstance. As such, the article interrogates how these fault lines are constructed amongst victims themselves through activism and discursive practice, and how these are either reified or challenged through legal and non-legal processes. It argues that the victim of approach can at one level reflect discursive battles over the legitimacy of certain acts of violence, yet on the other hand it also reflects the practical reality that different harms create different needs which require different means of redress. The inevitable consequence of the victim of approach, the article argues, is to introduce a process of hierarchisation 
evidenced in hierarchies of victims, hierarchies of perpetrators and hierarchies of harms. It concludes by arguing that hierarchisation process creates an invisible category of victims of the peace that existing transitional justice discourses and processes fail to recognise.

At this point the debate on whether non-state actors can violate human rights per se should be acknowledged. That they can inflict serious harm is beyond question, but whether this is labelled human rights abuse or a breach of domestic criminal law has long been a lively debate within human rights scholarship. ${ }^{10}$ Traditionally human rights law was charatersied by state-centricism and made a distinction between the state and anything that is 'not-a-state', ${ }^{11}$ with only the state being bound by human rights treaties it had negotiated and entered into. ${ }^{12}$ However, given the growing presence and influence of powerful non-state entities including oppositional armed groups, private security companies, financial institutions and transnational corporations, Gunter Teubner suggests that the primary distinction should now simply be 'legal/illegal'. ${ }^{13}$ Indeed, the expansion of international criminal law and international humanitarian law norms, and the approach taken in practice by bodies like the International Criminal Court (ICC), the International Committee of the Red Cross (ICRC), the United Nations (UN), truth commissions, and various human rights bodies, have arguably transcended traditional state-centrism and made it acceptable to discuss the actions of non-state actors as both illegal and a breach of human rights. ${ }^{14}$

Victim of a particular perpetrator

While victims are now central to the field of human rights, ${ }^{15}$ this has not always been the case. The prominence of the victim to international human rights and transitional justice today contrasts with their practical invisibility during the initial response to the mass human rights violations committed during World War II. ${ }^{16}$ During the Nuremburg trials victim were arguably viewed in instrumental terms as witnesses required to secure prosecutions as well as the symbols require to legitimate the punishment of the Nazis by the Allies rather than as the actual rights holders that they are recognised as today.${ }^{17} \cdot{ }^{18}$ Of course since WWII victims also emerged as key actors in the domestic criminal sphere in settled democracies and indeed were adopted by right leaning political actors as the justification for a more punitive response to crime. ${ }^{19}$ The intervention of left leaning radical and critical victimologists also helped expand understandings of victimhood as a human rights matter which encompassed victimisation by state violence, structural inequality and conflict. ${ }^{20} \mathrm{Just}$ as transitional justice became infused with human rights discourses in the $1980 \mathrm{~s}$ and $1990 \mathrm{~s},{ }^{21}$ so too have emerged domestic and international victims groups come to speak increasingly of human rights violations and emphasising in particular the harms inflicted upon the most vulnerable and marginalised including people of colour, women and children. ${ }^{22}$ 
While transitional settings and settled democracies have seen greater prominence given to victims' rights and interests, both also illustrate the potential for the politicisation of victimhood including by pitting victims against their victimiser and framing them as binary opposites. ${ }^{23}$ While this phenomenon is well known in settled democracies, ${ }^{24}$ the 'politics of victimisation' at the international level is arguably all the more powerful in transitional justice given the scale of past abuses and the often close relationship between broader ethno-political contests and the ways in which victims, victimisers and victimisation is understood. ${ }^{25}$ For example, 'victor's justice' has long been used a shorthand to differentiate between human rights violations dependent on who the victim was and who the victimiser was. ${ }^{26}$ In choosing which harms and atrocities are recognised and punished, ${ }^{27}$ bodies like the ICC have the power to legitimise certain victims and to punish certain perpetrators which can in itself have a significant discursive impact on how those harms (and, of course, those who inflict them) are understood. ${ }^{28}$

This evidences how the label 'victim' is not a purely descriptive one, but can be an interpretive one that reflects the mutual discursive interrelationship between victim and victimiser. ${ }^{29}$ Where the label is interpretive, it is not the causal link per se that is most pertinent but rather the discursive framing of those labelled as victim, those labelled as victimiser and the act(s) that bind them together. The significance of this interpretive process lies in the fact that defining the victim brings the concomitant ability to define the perpetrator and the harm they committed. ${ }^{30}$ This, of course, allows interpretations of past harms and the contexts within which they occurred to be infused with political and ideological understandings of the past more generally. Where and when victims are separated into 'good' and 'bad' victims dependent on their victimiser, for example, Madlingozi argues that we are really making a statement about the 'justifiability' of the harms inflicted on certain communities during conflict. ${ }^{31}$ The issue becomes less about victims per se and more about making a political and/or moral claim about the causes and consequences of the conflict within which their victimisation occurred, ${ }^{32}$ thus transforming victimhood into 'the terrain on which the political contests of the past are fought' ${ }^{33}$

Accordingly, labels like victim and perpetrator assume a value-laden significance in accordance with competing views of the conflict itself; the term victim is often linked to notions of innocence while the term perpetrator is more readily associated by ideas of guilt, blame and moral inferiority. This moral framing also extends to how the act of victimisation is labelled. The term 'victim', then, no longer signifies simply someone who has been victimised but also comes to speak to a set of assumptions about the victimiser and the act of harm itself. The term thus assumes a consequential quality whereby it becomes 'the pathway to assistance, sympathy, and the shedding of responsibility for violence, and indeed critical for the very moral justification of a people and a cause' ${ }^{34}$ 
Particularly in contexts where the past is still contested like the Basque Country and the North of Ireland, there is a strong preference for the 'ideal victim' versus 'ideal perpetrator' framework. ${ }^{35}$ This removes any culpability from the innocent and blameless victim and places it on their mirror opposite, the morally inferior victimiser. ${ }^{36}$ This 'fallacy of false dichotomy' suggests 'one person acts; the other is acted upon. One harms; the other is harmed. One is evil; the other is good. One bears responsibility; the other none' ${ }^{37}$ Collectives thus engage in 'competitive victimhood' whereby they try to ' $w i n$ ' 'ideal victim' status through such zero-sum analyses. ${ }^{38}$ By its very nature, the concept of 'competitive victimhood' implies that just like any other competition someone has to 'win' and someone has to 'lose'; the net result of this is that, for some victims at least, if you 'win' victim status you monopolise passivity, innocence and being harmed, while simultaneously projecting moral inferiority, guilt and blame onto those who have 'lost'. In the worst case scenario, such victim related debates about guilt and innocence can then be applied more broadly at the macro-level as to who was responsible for the causes and consequences of the conflict itself.

Studies on Northern Ireland and the Basque Country show that discursive strategies used to 'win' competitive victimhood include 'rule of law' narratives that differentiate between state and non-state violence, macabre number games that overlook the majority of state human rights violations falling short of death, and framing conflict as 'terrorism' ${ }^{39}$ Separating collectives into binaries of victim and perpetrator like this is ofcourse overly simplistic and overtly ideological ${ }^{40}$; it couches human rights violations that are substantively the same in different qualitative terms designed to legitimise and favour certain parties to the conflict over and above others. The natural consequence is that the victims of certain parties are favoured and legitimised over and above other victims. This fosters an 'exclusive victim consciousness' that fails to recognise the victimhood of others by presenting the 'self' as the most, or even uniquely, victimised. ${ }^{41}$ This is evident in victim discourses that adhere to the premise of being a victim of a certain perpetrator seen in a number of sites. For example, in Israel the term nifgei terror is a term for victims of 'terror' that is restricted to Israeli civilians killed by Palestinians. ${ }^{42}$ Similarly, in the Basque Country and Northern Ireland, the term 'innocent victim' has been adopted to refer exclusively to the victims of non-state violence rather than victims of state violence. $^{43}$

This approach of framing victimhood in terms of the victimiser instead of the victimisation is also prevalent in victims' group activism and mobilisation. For example, in Nepal the Maoist Victims' Association (MVA) largely excludes victims of the state security forces and the Society of Families Disappeared by the State (SoFAD) excludes those victimised by the Maoists. ${ }^{44}$ Likewise, in Israel Natal (The Israel Trauma Center for Victims of Terror and War) adopts an exclusivist approach to victims' rights activism by advocating for the rights of a narrowly, and politically, defined set of victims. ${ }^{45}$ In 
the North of Ireland, the victim of debate largely shapes the organisation of victims groups (with one or two notable exceptions like WAVE Trauma Centre) with victims groups organised along lines that mirror the Nationalist - Unionist political divide. ${ }^{46}$ For example, HAVEN is a victims group where the common denominator is that they have been impacted by '[Irish] republican violence' ${ }^{47}$ In some cases 'innocent victims' groups in Northern Ireland function as conflictual social movements in existing only to stand in opposition to a clearly identified 'other' victim constituency. ${ }^{48}$ At the core of their victim of identity is a rejection of 'moral equivalence' between state violence that was exercised in pursuit of the 'rule of law' and non-state violence - invariably labelled as 'terrorism' - that was exercised in contravention of the 'rule of law'. ${ }^{49}$ In South Africa, this victim of dynamic was reversed to reject equation between the systematic human rights violations of the Apartheid state and those abuses committed by armed groups fighting against that state. ${ }^{50}$ As noted above, when the victim of phenomenon manifests itself in such a fashion, it focuses on who carried out the harmful acts rather than concentrating on nature and effect of the acts in question which also reduces the opportunities for commonality based on the shared experience of having been victimised. ${ }^{51}$

While there is politically advantageous discursive value in contesting the victimhood of others, there is also a strategic benefit in an environment where there is only limited resources allocated to meeting the multifarious needs of victims. As such, the rhetorical battle over blame and guilt can in some instances be transformed into a material battle over resources. This can create discontent when the allocation of resources is seen to favour the supposedly less innocent at the expense of seemingly more deserving victims. For example, the decision to hold multi-million pound inquiries into a number of high profile cases of state violence in the North of Ireland was criticised by one 'innocent victim' group who asked 'what's the difference between that case and any of ours?'. ${ }^{52}$ In direct contrast to the Northern Ireland situation, the more favourable material benefits available to veteran's groups in Bosnia has seen victims avoiding, rather than embracing, the 'innocent victim' label. In that context, some families of civilian dead have falsely claimed their relatives as armed actors and the civilian injured have claimed that their injuries are battle sustained in order to access pensions and other benefits. $^{53}$

Admittedly, some cases do depart from the strictures of this ideologised victim of approach. Examples from Northern Ireland are again instructive. While some 'innocent victims' groups have married victims' advocacy with ideological activity designed to propagate a particular narrative of the past, other victims' groups have been apolitical in only advocating for the provision of services to victims. ${ }^{54}$ Likewise, some Unionist victims have sought common ground with Irish republicans harmed through the conflict. For example, Alan McBride who lost his wife in the Shankill Road bomb attack 
acknowledged the equivalence of grief he shared with the family of Irish Republican Army (IRA) bomber Thomas Begley who died planting the same device. ${ }^{55}$

Competitive victimhood over resources and media coverage can also surface within the same constituency. Take for example the families of the 11 people shot dead in Ballymurphy by the British Army six months before the Bloody Sunday killings in Derry. While Bloody Sunday has been well publicised, subject to a public inquiry and seen an apology from the British state, the Ballymurphy families argue that they have been 'completely wiped out of the story'. ${ }^{56} \mathrm{Here}$, competitive victimhood is devoid of anti or pro state ideological contestation (both groups are from the nationalist community and both suffered at the hands of the British army) because it is primarily about reversing the invisibility of one's victimisation in public discourses that afford other victims hyper-visibility.

The victim of approach can also be found in the definitional provisions of victims' legislation. In the case of the Basque Country, the Act on Victims of Terrorism stipulates that victimisation must arise from an act of 'terrorism'. ${ }^{57}$ In theory this appears to eschew the issue of who the perpetrator is. However, since the state defines 'terrorism', it is invariably a label applied to non-state violence only. In Colombia the significance of the victimiser's identity is even more stark. In that context, Law 975/2005 fails to recognise the existence of an armed conflict and as such refuses to see the state as an actor in the conflict. ${ }^{58}$ State actors and their transgressions are therefore placed outside its remit. This effectively places the 'rule of law' narratives favoured by certain victims' groups onto a formal legislative footing in a way that privileges victims of non-state violence over victims of state violence. By contrast, in Northern Ireland the legislative definition of victim under the Victims and Survivors (Northern Ireland) Order 2006 challenges the victim of approach by focusing exclusively on the harm suffered rather than on who inflicted it. This definition is even more inclusive than that found in some international documents. ${ }^{59}$ Unsurprisingly, it has been rejected by some 'innocent victims' because it contributes to 'moral equivalence' by failing to exclude those who were both victim and victimiser. As a result, 'innocent victims' campaign group Innocent Victims United launched a victims' charter demanding a change to the legislative definition of victim. ${ }^{60}$

The victim of a particular perpetrator typology represents the clearest manifestation of ideological division among victims of human rights abuses. In seeking to make a moral argument about the (il)legitimacy of respective parties to a conflict, it focuses on the victimiser rather than the victim. It implies that the status and worth of the victim is somehow contingent on that of the victimiser, and in doing so it creates a hierarchy of victims that can, and has, been co-opted into official responses. Because there is an intrinsic link between victim and victimiser, a hierarchy of victims presupposes a concomitant hierarchy of perpetrators. ${ }^{61}$ Like the former, the latter is not only ideological but has also 
seeped into official responses to human rights abuses. Legal responses have been seen to feed into ideological notions underpinning a hierarchy of perpetrators by punishing, sanctioning and censuring certain perpetrators through criminal prosecution, lustration or exclusion from the definition of victim while failing to do the same with other perpetrators who committed similar harms under an opposing ideological guise. ${ }^{62}$

It must be noted that the victim of a particular perpetrator approach has minimal applicability to structural injustice and/or socio-economic rights that are often seen as 'agentless' crimes. ${ }^{63}$ As such, it is difficult to identify any victimiser that can be punished in the name of victims, which cuts against the narrative of transitional justice as accountability. ${ }^{64}$ While it is important to acknowledge this fact here, its ramifications are examined below with regard to the hierachisation of harms.

\section{Victim of a particular harm}

If being a victim of a particular perpetrator operates according to ideological hierarchies of victims and hierarchies of perpetrators, then the premise of being a victim of a particular harm operates according to a hierarchy of harms. A hierarchy of harms, though, is not detached from a hierarchy of perpetrators. As well as differences in the harms state or non-state actors are primarily responsible for ${ }^{65}$ there is also an unequal visibility of these harms and their victims. ${ }^{66}$ Whether everyday harms committed by the state apparatus like prolonged detention, mass surveillance and controlled movement are recognised or not will significantly influence the framing of victims, victimisers and the conflict itself. ${ }^{67}$ This hierarchisation of harms manifests itself in three ways. Firstly, by prioritising the victims of certain harms over the victims of other harms. Secondly, by trying to quantify different levels of harm. Thirdly, by completely excluding certain harms altogether.

At the macro-level such dynamics may mask structural factors such as the fact that the victims of harms such as torture belong to the poorest and most marginalised sections of society and this may struggle to mobilise and have their voices heard. ${ }^{68}$ At the micro-level this can see some victims within victims' groups sively downplay their own experiences of harm where they have been injured through an incident in which other members of the group were bereaved. ${ }^{69}$ In other cases the downgrading of harm experienced by particular victims is foisted upon them by other victims. For example, victims of certain human rights violations such as internal displacement, torture and detention in Peru have seen other victims devalue their victimhood by implying that they must have been engaged in 'terrorism' to have been so harmed. ${ }^{70}$ Consequently, there has been a friction among Peruvian victims based upon the harms they have suffered. ${ }^{71}$ A recent mobilisation in El Salvador, by way of illustration, sought to get a comprehensive reparation law legislated to provide reparations for those victimised and bereaved through a multiplicity of harms. ${ }^{72} \mathrm{~A}$ similar campaign to secure reparations in Northern 
Ireland has focused on providing a 'Troubles pension' but only to those who were severely physically disabled rather than those otherwise victimised. ${ }^{73}$ While this campaign has been important in the absence of other reparation payments, it has been held hostage to political disagreement as to whether or not a very small number of non-state actors should qualify for it.

The hierarchisation of harms is again discernible in legal responses to human rights abuses. Legal responses are, of course, taken within a broader context where there has been longstanding debate within human rights scholarship about a hierarchy of human rights. ${ }^{74}$ The protection from some harms, like torture for example, has been given a non-derogable status that sets it apart from other human rights obligations that states may derogate from in times of public emergency. ${ }^{75}$ An explicit hierarchy can also be found under the international law 'duty to prosecute' those human rights abuses deemed the most grievous - genocide, war crimes, and crimes against humanity. ${ }^{76}$ Even here the structural factors behind hierarchisation are masked given that the thresholds of grievousness needed under international law place certain very serious harms beyond the reach of this duty. ${ }^{77}$ International human rights law, with its emphasis on investigating and punishing violations that fall into a categorisation of 'most serious', has the effect of making anything that fits this categorisation visible while obscuring harms that do not fit. ${ }^{78}$ This prioritising of certain harms over others has seeped into domestic provisions. In Colombia this was by express exclusion whereby certain human rights violations were labelled as criminal acts, thus placing them outside the ambit of the law 975/2005 reparation programmes. ${ }^{79}$ In Bosnia it was by way of quantifying harm through technical criteria that meant victims of torture only qualified as civilian victims of war if they could demonstrate permanent harm that reached a particular severity. ${ }^{80}$

Non-legal mechanisms have also exhibited the victim of approach. Here, however, the matter may reflect the practical reality that some mechanisms and processes can only meet the needs of victims impacted by certain harms. For example, someone who is suffering from physical or psychological injury experienced as a result of a particular harm will have different needs to those who suffered socio-economic harm through a similar act of harm. Likewise, internally displaced persons might pursue a right of return whereas those victimised through enforced disappearance will pursue the return of their loved ones remains. Because the differing harms require different remedies it is unlikely that a single mechanism can redress both. Hence in Northern Ireland the Independent Commission for the Location of Victims Remains (ICLVR) was integral to helping the families of those disappeared learn about the fate of their loved ones and in the majority of cases to recover their remains. ${ }^{81}$ Acting on information provided under 'use immunity' (ie nothing provided to or recovered by the body could be admissible in criminal proceedings), the Commission engaged in extensive exhumations at a number of sites pinpointed by those groups responsible for the disappearances. ${ }^{82}$ Nevertheless, for 
the vast majority of those bereaved through the conflict it offered nothing because less than $1 \%$ of those killed were disappeared. In Nepal the Interim Relief Programme offered financial and medical relief to the families of those killed and missing but did not extend its work to victims of sexual violence and torture. ${ }^{83}$ There is a vital difference here between the outworkings of the victim of approach in this context and that of the ICLVR in the North of Ireland; with the ICLVR this is dictated by practicalities of only being fit to respond to certain needs arising from a particular harm whereas with the Nepalese relief programme it reflects a conscious decision to prioritise the needs of those harmed in certain ways by excluding those harmed in other ways. One is determined by necessity, the other by choice.

This reflects a necessary selectivity that lies at the heart of transitional justice programmes such as reparations. The sheer scale of victimisation through conflict leaves it 'unworkable' in any practical sense to give everyone material reparations ${ }^{84}$ Reparative packages for victims are drawn from the same budget that has to provide housing, healthcare and education in post-conflict society. ${ }^{85}$ While some have questioned the wisdom of putting a price tag on harms, ${ }^{86}$ reparations extend beyond material forms of payment to also include services and support in the forms of educative training, healthcare and therapy. ${ }^{87}$ Although this reflects the broader range of harms suffered, the reality remains that whether it is in the form of compensation payments or other rehabilitative services these all cost money. By necessity, then, a hierarchical approach to harms emerges when a decision is made to offer payment or services to those affected by certain harms but not to those impacted by others. This essentially means that the post-conflict human rights discourse puts differential value on different forms of harm. ${ }^{88}$

In turn, this can lead to an additional form of 'competitive victimhood' that is predicated on harm suffered rather than on the perpetrator responsible for it. This exclusivist dynamic was even evident in the first phase of transitional justice where post -World War II compensation schemes wrestled with the notion of which modes of victimisation (i.e. harms) to include and exclude and, as a consequence, which victims to include and exclude. ${ }^{89} \mathrm{~A}$ hierarchal approach to harms is also evident where there is disparity in the level of reparations awarded to victims. In Tunisia, for instance, reparations were awarded to 'martyrs and the wounded of the revolution', with 6,000 Dinars paid out to 2,749 wounded and 40,000 Dinars paid out to the families of 347 martyrs.${ }^{90}$ Here, being martyred for the revolutionary cause is clearly seen as more worthy of reparation than being injured for it is. As a result, the hierarchy of harms dictates that the families of the martyred dead are given greater financial reparation than the wounded are.

It may be helpful at this stage to apply the theoretical victim of a particular harm lens to empirical cases; one geographical and the other thematic. South Africa is a useful example to draw out how a 
victim of approach can seep into reparative responses to human rights abuses. The country has the most notable example of the truth commission mechanism. Although primarily a mechanism for truth recovery, ${ }^{91}$ truth commissions are also said to offer victims of human rights abuse symbolic justice through recognition and material justice through reparation payments too. ${ }^{92}$ However, studies on the country's Truth and Reconciliation commission (TRC) suggest that neither of these were universally available. In terms of providing symbolic reparation like recognition and voice, it has been consistently argued that the TRC privileged the voices of a certain kind of victim - i.e. 'the forgiving victim' -because that is what suited the political agenda in the 'new nation' ${ }^{93}$ Selectively offering discursive space to certain victims whose voices were heard in the TRC was mirrored in the selective dispersal of material reparations. While reparations are available under the Presidents Fund, they are only awardable to those identified as victims by the TRC. ${ }^{94}$ The difficulty here is that the TRC made a distinction between victims of particular harms; a victim was officially held to only be those harmed through certain defined human rights violations rather than through the wider structural impact of Apartheid. ${ }^{95} \mathrm{~A}$ distinction was therefore made between missing out on particular opportunities due to the limits on equality of opportunity the Apartheid system imposed and missing out on these same opportunities through something defined as a gross human rights violation under the TRC mandate. The latter were eligible for redress through reparative programmes but the former were not despite the same adverse outcome.

More problematically, the TRC had to adjudicate on matters like whether arson qualified as a gross human rights violation or not. The conclusion reached was that arson could so qualify if one had to move home because of the arson attack but not, somewhat oddly, if one had lost their livelihood or livestock because of it. ${ }^{96}$ Victimhood hinged in this instance on a strict technical criteria relevant to a particular harm. While technicalities have denied reparation to certain arson victims, those harmed in other ways have had financial help made available to them. By way of an example, R35 million was earmarked to help the reburial costs of the exhumed remains of missing persons reported to the TRC. ${ }^{97}$ The exclusivity threaded through the TRC reparations programme has been criticised by victim support group Khulumani for creating a class of 'more advantaged victims' while at the same time overlooking more than 100,000 others who have legitimate claims to reparations as victims of Apartheid. ${ }^{98}$ The tensions within the victim constituency in South Africa has meant that many who have been awarded reparation payments chose not to disclose this to friends, family or their community due to potential ill-feeling. ${ }^{99}$ Just as the ideological premise of the victim of a particular perpetrator approach has created politicised division within victim constituencies over innocence and blame, so too has the technical restrictions on the victim of a particular harm approach fostered divisive ill-feeling and competition. 
If South Africa is a useful geographical case study, then gender is an equally useful thematic example. While genocide sits atop of the hierarchy of harms, gendered harms have, traditionally at least, been located considerably lower down that hierarchy. Historically, what some have termed the the 'masculinist' approach of international law initially framed sexual violence as the 'collateral damage of warfare', failing to adequately provide reparation or accountability for it. ${ }^{100}$ The Nuremburg and the Tokoyo trials effectively ignored the issue of war time rape. ${ }^{101}$ This relegated gender-based harms to a lesser status than other human rights abuses. This was only belatedly addressed through the latter work work of the ICTR and the ICTY, and then further formalised by the Rome Statute of the ICC that recognises rape, sexual enslavement, enforced sterilisation and other gender-based sexual crimes as war crimes. ${ }^{102}$

While certainly welcome, the gradual recognition of gender-based harm has not been a panacea. Yes, truth commissions and courts have provided a platform for female testimony. However, at the same time they have tried to reductively frame gender-based harms as invariably sexual which in itself elides the wider structural causes of human rights abuses committed against women because they are women. ${ }^{103}$ The failure to examine the socio-economic factors behind structural abuses of human rights in these fora produces gendered results that almost caricatures female experiences of conflict. ${ }^{104}$ This causes a double hierarchisation: the initial favouring of non-gendered harms over gender-based harms and then the subsequent favouring of sexual violence over other non-sexual and non-violent gendered harms. The net effect of this is to, at worst, invisibilise and, at best, recognise but leave unaddressed a multitude of gendered harms that fail to fit the preferred model of sexual harms. Either way, certain gendered experiences fall into a semantic and legal black hole despite the fact that they are very clearly gendered in nature. There were, for instance, gendered ramifications for female FARC guerrillas who reported experiences of birth control, informal adoptions and enforced abortions. ${ }^{105}$ Likewise, in certain areas of Sri Lanka forced marriage was seen as a means of preventing female offspring from being forcibly recruited to the Tamil Tigers. ${ }^{106}$ Both of these experiences speak to the gendered experiences of conflict that cannot be captured in discursive or legal attempts that reduce female experiences to that of the passive victim of war time rape.

This is not to suggest that war time rape is now adequately addressed in post-conflict societies. In some contexts like Cambodia a cultural and societal taboo has served to elide over sexual violence under the Khmer Rouge regime. ${ }^{107}$ In other contexts such as Sierra Leone, women who testified to sexual harms at the truth commission were later ostracised by their communities. ${ }^{108}$ This shows that even where the issue is openly addressed and where victims have tried to assert their voice problems remain. Thus, groups like the Bosnian organisation Woman Victims of War exist to specifically represent female victims of war-based sexual violence. ${ }^{109}$ In some cases, civil society has intervened 
in an attempt to empower victims of gendered harms. They have sought to dispel the 'meta woman experience' myth often seen in international legal processes where women are couched as victims and encouraged to testify in accordance with a dominant script of sexual violence. ${ }^{110}$ To this end, an innovative project in the former Yugoslavia set up a Woman's Court in Sarajevo with the purpose of giving voice to women who had been victimised in the region by allowing them to tell of their experiences of gendered harms to a collective audience. The project is driven by the desire to provide justice as recognition to women there who had felt let down by the formal criminal justice process that was only interested in the formal legal value of their testimony and not in the ripple effect their victimisation had on them, their families and communities. ${ }^{111}$ The inadequacies of the victim of approach in official mechanisms birthed a non-official attempt to counter hierachisation of gendered harms. Existing legal and non-legal mechanisms failed to deliver for victims of sexual harms so these victims responded by devising their own mechanism to meet their own needs.

While this shows that the hierarchy of harms can, and has, been challenged by victims on genderbased grounds, it seems less certain that it can be challenged to the same degree and with the same results by victims on other grounds like class, ideology or race. The hierarchy of harms, and indeed the hierarchy of victims and the hierarchy of perpetrators, may prove more resilient to challenges from more problematic victim constituencies. This is most relevant where some victims have their victimhood politically contested because they have a simultaneous victimiser identity too, or because their victimisation stems from structural harms that are ideologically, culturally or socially difficult for others to acknowledge and/or accept. It is to such difficulty attention now turns.

\section{Victim of circumstances}

Finally, it is possible to define someone as a victim of circumstances where victimisation arose from structural, cultural or political factors. This resonates with the structural dynamics which often undrpin collective violence. Certain groups can have 'victim proneness' by dint of their lowly socioeconomic status or their particular socio-political framing. ${ }^{112}$ Such groups often fall victim to harm ranging from displacement, dispossession and ethnic cleansing. Moreover, certain harms like genocide are inescapably structural in nature given that victims are targeted on the basis of group membership rather than on the basis of any individual conduct. ${ }^{113}$ In particular, two groups are well placed to fit the victim of circumstance typology: those labelled 'indirect victims' because their status as victim derives by proxy from a relationship to someone else who directly experienced the harm, and those labelled 'complex political victims' who can be seen as victims of human rights abuse even though they committed human rights abuses of varying degrees themselves. 
In terms of 'indirect victims', Borer has labelled the families of those actively involved in conflict as 'victims once removed' by virtue of them suffering a broken home and increased deprivation, and, in some cases, as 'victims by proxy' where they were themselves later victimised on the basis of their relative's activities. ${ }^{114}$ In some cases these victims may have encountered a form of double victimisation through social exclusion and ostracising. In Francoist Spain, for instance, the families of those killed or disappeared by the regime suffered secondary victimisation whereby they were ostracised by neighbours, had properties taken from them and were excluded from certain jobs. ${ }^{115}$ This stigmatisation is analogous to that encountered by children conceived through war time rape. Although these victims are the product - literally - of harms that they did not themselves experience or that they had no agency in, they are often placed at the margins of post-conflict society. ${ }^{116}$ They fall victim to the 'stickiness of shame' that attaches itself to children born through war time rape. ${ }^{117}$ This has implications for the place of such victims in the post-conflict environment as discussed further below.

Notwithstanding these cases, legal responses to human rights abuses have been cognisant of 'indirect victims'. The ICC's Rules of Procedure and Evidence allows 'indirect victims' - like family members who did not suffer the actual harm - to access reparation payments on their own behalf, ${ }^{118}$ while the jurisprudence of the Inter-American Court of Human Rights has recognised 'indirect victims'. ${ }^{119}$ By the same token, the 2005 UN Basic Principles and Guidelines recognise an extended concept of 'indirect victim' that extends beyond the immediate family of the direct victim. ${ }^{120}$ Furthermore, a similar trend is evident in domestic legal responses to reparations. Payments relating to 'martyrs of the revolution' in Tunisia, to those disappeared in South Africa and to those murdered in Nepal, as previously discussed, are all awarded to 'indirect victims' because they are being made to the families of those victimised through these harms rather than to the dead and disappeared themselves.

'Complex political victims', in being those who can be considered to have in some way created the space for their own victimisation, ${ }^{121}$ pose a challenge for transitional justice processes. They are difficult for transitional justice mechanisms and discourses because they reflect the complex lived reality of conflict that defies neat categorisation into easily distinguishable boxes like victim and perpetrator. ${ }^{122}$ However problematic this category may be, it is nonetheless imperative that they are afforded due recognition because if they are not particular groups will be excluded in a way that impinges on the transitional process. ${ }^{123}$ The 'complex political victim' phenomenon can be evaluated through the case of non-state actors in the North of Ireland. This group possess a complex multilayered victimhood. They are victims of circumstance given that they were born into a conflict and came from socio-economically deprived communities. They were 'indirect victims' given that many lost family and friends during the conflict. They, in turn, created 'indirect victims' through the socio- 
economic impact of their imprisonment, as well as direct and indirect victims through their own violent role in the conflict. Moreover, they were direct victims of particular harms like brutalisation during police detention and imprisonment. ${ }^{124}$ While other victims might question their claim to victimhood, ${ }^{125}$ in being born into marginalised communities that were embroiled in political violence this category inflicted and experienced harms in a structural context they found themselves in rather than in one they themselves had engineered. ${ }^{126}$ This is not, however, to strip such actors of their agency. For sure, they may not have determined the circumstances they were born into but they did determine how they responded to these circumstances. Others in similar circumstances chose not to become involved in political violence. ${ }^{127}$ Yet the significance of having to make a decision either way against this structural backdrop has even been acknowledged by some victims of non-state violence.

Alan McBride, the victim mentioned above, recognised this when he argued that circumstance as much as moral choice can dictate where one finds oneself in the hierarchy of victims, proceeding to then ask 'if I had been born into Thomas Begley's circumstances, and he into mine, would I have been the one who grew up to plant a bomb that killed his wife?'. ${ }^{128}$ Of course, this point is not restricted to the Northern Ireland context or to non-state actors. It can easily be extrapolated out to other sites and actors too. In South Africa, for instance, a case has been made that young Afrikaner soldiers and policemen were victims of a militarised society that brought them up as conscripts and subjected them to indoctrination on the need to fight the evils of communist 'terrorism' ${ }^{129}$ Just like non-state actors in the North of Ireland, these individuals are the victims of a structural situation they were not responsible for, even if they were responsible for certain human rights abuses during the conflict that emerged out of that structural backdrop.

Child soldiers are the case par excellence of victims of circumstances who also happen to be victimisers. ${ }^{130}$ While this group are doubtless participants in a regime of violence they are also equally victims of it too. This regime subjects child soldiers to particular harms like abduction, drugging and forced conscription, before creating an environment where these victims themselves go on to commit other harms. ${ }^{131}$ Dominic Ongwen is a prime example of the multifarious dimensions to being a victim of circumstances. Although Ongwen stands accused of gross human rights violations, he himself was abducted by the Lord's Resistance Army (LRA) as he walked to school along with other children, some of whom were able to run more quickly and evade capture. ${ }^{132}$ Ongwen is therefore a victim of circumstances on two levels; on the level of being a 'complex political victim' who was abducted and forcibly recruited before later engaging in human rights abuses himself, and on the level that it was only happenstance dictated that he, as opposed to someone else, would not be able to evade capture. 
This shows that the process of being a victim of circumstances relies on a myriad of factors where structural backdrops, familial links and bad luck collide to produce a class of victim transitional justice discourses and processes struggle to deal with. This creates a complexity that ultimately leads to the failure to adequately cater for such a constituency of victims. This failure can take the form of express exclusion or it can take the form of failing to tackle the structural causes of particular harms. While transitional justice processes premise themselves on restoring the 'civic status' of all those effected by war and conflict, ${ }^{133}$ in some cases these processes operate to an exclusivist, rather than inclusive, dynamic whereby the victims of circumstances are at best invisibilised and at worst deliberately excluded. It is to a further examination of this exclusivist dynamic the article now turns.

\section{Victim of the peace}

Where and when transitional justice discourses and processes exclude problematic groups, victims of circumstances during the conflict are transformed into victims of peace in post-conflict societies. This transformation manifests itself in two ways; economically, in a way that can be tangibly and materially measured, and socially, in a less tangible yet more discursive way. ${ }^{134}$ Even if the context that frames their current reality has been re-labelled 'peace' instead of 'conflict', victims of the peace find themselves either re-experiencing previous harms or experiencing newer, but similar, harms.

It is worth returning to the case of children born through war time rape at this juncture. While they may experience harms like infanticide during conflict, ${ }^{135}$ their transformation from victims of circumstances into victims of the peace rests on two factors; the 'normative stigma' that frames them as a threat to their mother and her ethnic group, ${ }^{136}$ and the 'accountability gap' they find themselves existing within under international criminal law and transitional justice processes. ${ }^{137}$ Concerning the normative stigma, in Rwanda discourses that frame such children as the 'children of killers', rather than as victims in their own right or as children of rape victims, places them at the margins of a society increasingly said to be 'moving on' after genocide. ${ }^{138}$ The ramifications of being presented in this way are twofold; discursively it creates an identity crisis and materially it drives them into poverty given that their mothers often receive little familial or communal support and that many do not qualify for governmental assistance as victims of the genocide because they were born after $1994 .{ }^{139}$ Uganda is another case in note, where children born through LRA sexual violence against abductees are given the pejorative label lutero luke (analogous to 'bastard') and forced into a life of exclusion and poverty. ${ }^{140}$ Although NGO's provide training and start up capital to these victims, cultural norms around parental lineage disadvantages them in inheriting land, while discrimination means that they often struggle to gain employment related to their new skill sets in a society that continues to exclude them. ${ }^{141}$ 
In other contexts, the 'accountability gap' has either invisibilised or excluded children born through war time rape. In Colombia, for instance, no such children have received reparations under the Victims and Land Restitution Law 1448 yet. ${ }^{142}$ This is mirrored in international criminal law, with the same group of victims finding themselves absent from some key ICC policy documents. ${ }^{143}$ As Joanne Neenan argues, the crux of this problem is that the approach to enforced pregnancy was formulated as part of a broader push to internationally criminalise gender-based war harms against women rather than with the rights of the child mind. ${ }^{144}$ The victim of the peace is therefore not the intended beneficiary of the existing approach. Recent developments in the Bemba case, however, suggest that the ICC might finally award reparations to children born through war time rape. ${ }^{145}$ Until and unless this happens, though, these victims of circumstances will continue to become victims of the peace through discursive 'othering', continued material deprivation and invisibility and/or exclusion under transitional justice processes.

Likewise, Disarmament, Demobilisation and Reintegration (DDR) processes have often come up short in their purported aim of restoring the 'civic status' of former combatants. ${ }^{146}$ This can occur where gendered dimensions are reified rather than challenged and where deep seated socio-economic factors underpinning conflict are neither acknowledged nor addressed. In terms of the former, while gender related rehabilitative measures should meet the immediate needs of those they are aimed at, they should also have long term utility in helping to change the structural reality that allowed gendered harms to take place in the first place. ${ }^{147}$ In many cases, however, DDR processes have failed to progress beyond the first stage, thus effectively freezing, as opposed to changing, the gendered status quo. Hence in Sri Lanka female ex-combatants have either been placed at the margins of their communities where they continue to experience gender-based abuse or else they have been 'reintegrated' through gender segregated programmes that restrict them to stereotypical gendered industries and roles that are low paid. ${ }^{148}$ In terms of the latter, DDR processes, or sometimes the express lack of them, have failed to lift former combatants out of the poverty and marginalisation they were born into. ${ }^{149}$ In many cases this means that they are being 'reintegrated' back into the poverty that birthed and sustained conflict rather than into the socio-economic betterment that transition seemingly offers. These victims of circumstances, then, are finding themselves in the same, rather than improved, circumstances.

The case of non-state actors in Northern Ireland is again instructive. An extensive body of literature on these victims of circumstances has identified that they face a multitude of barriers to proper reintegration ranging from Post Traumatic Stress Disorder (PTSD), discrimination through 'residual criminalisation' and continued socio-economic deprivation through low paid employment or unemployment. ${ }^{150}$ While these problems arise in most DDR processes, ${ }^{151}$ in the North of Ireland there 
is the added complication of a politicised zero-sum analysis falsely depicting any attempt to tackle structural barriers to the reintegration of former combatants as working to the material detriment of their victims. ${ }^{152}$ With successful reintegration comprising genuine economic, political and social reintegration of former combatants, ${ }^{153}$ even a cursory glance of Northern Ireland's approach exposes shortcomings; economically former combatants have been consigned to low paid employment due to the barriers and exclusion presented by 'residual criminalisation', politically they have been subjected to repeated attempts to delegitimise them as bona fide post-conflict political actors, and socially they continue to be framed as the binary opposite of their victims which reduces them to being an outlet for the retributive desires of such victims that were carried over from the conflict into the imperfect process of transition. ${ }^{154}$ These victims of circumstances, then, become victims of the peace through discursive 'othering', continued material deprivation and what amounts to little more than scapegoating dressed up as victim centric transitional justice.

In sum, the above examples evidence how those victimised through structural and cultural factors can be re-victimised through the abject failure to adequately address these pervasive macro-level matters during transition. These victims of the peace are to be found at the foot of the hierarchy of victims (if found on it at all), and the continuing socio-economic and cultural harms they encounter during transition are at the foot of the hierarchy of harms. A multitude of unfavourable factors militate against them; in reflecting the messiness of conflict and transition they challenge the neat categorisation into rigidly defined binaries that transitional justice prefers, ${ }^{155}$ the harms that they continue to experience require fundamental socio-economic and/or cultural change that transitional justice has always avoided in favour of securing political and civil rights, ${ }^{156}$ and, where 'complex political victims' are concerned, it is difficult for transitional justice processes and discourses to 'see' past their role in creating, as opposed to being, victims. ${ }^{157}$ This has created a paradoxical quagmire; transitional justice mechanisms and discourses either fail to 'see' such victims of the peace at all, or conversely they only 'see' them through a lens of normative stigma. This perpetuates discursive 'othering' and material disadvantaging, with such groups 'seen' as victimisers - or at the very least a threat to other victims - to be excluded or punished in the post-conflict interests of victims rather than being 'seen' as victims of particular structural harms with their own rights and needs that should be addressed.

\section{Conclusion}

When transitional justice discourses, mechanisms and processes claim that they are serving the needs and interests of 'the victims' such a claim requires heavy qualification. Whatever their purported claims about serving 'the victims', they are often restricted in who they actually serve by practical and 
political limitations - practical due to limited resources and the differing needs arising from different harms, and political due to the intrinsic link between 'seeing' particular victims and/or modes of victimisation and particular ideological interpretations of the past. Macro-level discourses, however, more often than not disguise and invisibilise rather than acknowledge and confront this. A plethora of divisions within victim constituencies (which mirror wider societal divisions around race, gender and ideology) means that such processes and mechanisms can, at best, only cater for a select group of victims rather that for 'the victims' as such. The cumulative effect of this is that these discourses and mechanisms actually operate not on the premise of being a victim but on that of being a victim of - either as a victim of a particular perpetrator or as a victim of a particular harm. In the calculation of who to cater for, transitional justice processes and mechanisms invariably resort to a process of hierarchisation. As a consequence they construct, and then subsequently operate according to, hierarchies of victims, hierarchies of perpetrators and hierarchies of harms by choosing to prioritise and favour certain harms and victims over and above others. While sometimes underpinned by practical considerations, more often than not these hierarchies are thinly veiled ideological constructs designed to legitimise particular interpretations of the past through the medium of victimhood by 'seeing' some constituencies as 'ideal victims' and other constituencies as 'ideal offenders'. In many cases the hierarchies evident in official transitional justice responses have been co-opted into victim activism and discourses that operate along ideological, gendered and class-based lines.

Such hierachisation has had both material consequences where it has bred continued socio-economic marginalisation and disadvantage, and discursive consequences where it has contributed to the 'othering' of certain problematic victim constituencies. Hierarchisation has shown itself particularly unfavourable to gendered issues, either trying to reductively frame the issue as sexual in nature or through failure to address the deep seated socio-economic factors that birthed and sustained gendered harms. Likewise, hierarchisation has been detrimental for 'complex political victims', essentially transforming them from victims of circumstances into victims of the peace through continued discursive 'othering' and continued material deprivation. Accordingly, the net effect of the hierarchical nature of the victim of approach is that in some transitioning societies marginalised groups, like women and girls, children born through wartime rape and former non-state combatants continue to be discursively and materially disadvantaged in ways that are invisibilised in transitional justice discourses and by transitional justice processes that present themselves as otherwise victim centric.

\footnotetext{
${ }^{1}$ M. Cherif Bassiouni, 'International Recognition of Victims' Rights', Human Rights Law Review 6, no. 2 (2006): 203-279; Kora Andrieu, 'Confronting the Dictatorial Past in Tunisia: Human Rights and the Politics of Victimhood in Transitional Justice Discourses Since 2011', Human Rights Quarterly 38, no. 2 (2016): 262 - 293.
} 
${ }^{2}$ Laurel Fletcher, \& Harvey Weinstein, 'Writing Transitional Justice: An Empirical Evaluation of Transitional Justice Scholarship in Academic Journals', Journal of Human Rights Practice 7, no. 2 (2015): 177 - 198; Jairo Rivas, 'Official Victims' Registries: A Tool for the Recognition of Human Rights Violations', Journal of Human Rights Practice 8, no. 1 (2016): 116 - 127.

${ }^{3}$ Giada Girelli, Understanding Transitional Justice: A Struggle for Peace, Reconciliation and Rebuilding (New York: Springer, 2017)8.

${ }^{4}$ Kieran McEvoy \& Kirsten McConnachie, 'Victims and Transitional Justice: Voice, Agency and Blame', Social \& Legal Studies 22, no. 4 (2013): $498-513$.

${ }^{5}$ Tshepo Madlingozi, 'On Transitional Justice Entrepreneurs and the Production of Victims', Journal of Human Rights Practice 2, no. 2 (2010): $208-228$.

${ }^{6}$ Tristan Borer, 'A Taxonomy of Victims and Perpetrators: Human Rights and Reconciliation in South Africa', Human Rights Quarterly 25, no. 4 (2003): $1088-1116$.

${ }^{7}$ Tshepo Madlingozi, 'Good Victims, Bad Victims: Apartheid Beneficiaries, Victims and the Struggle for Social Justice', in Law, Memory and Apartheid: Ten Years after AZAPO v President of South Africa, eds. W. Le Roux \& K. Van Marle (Pretoria: Pretoria University Press, 2007): 107 - 126.

${ }^{8}$ Borer, 'A Taxonomy of Victims and Perpetrator'; Anna Bryson, 'Victims, Violence, and Voice: Transitional Justice, Oral History, and Dealing with the Past', Hastings International \& Comparative Law Review 39, no. 2 (2016): $299-354$.

${ }^{9}$ Kimberle Crenshaw, 'Mapping the Margins: Intersectionality, Identity Politics, and Violence against Women of Color', Stanford Law Review 43, no. 6 (1991): 1241 - 1299.

${ }^{10}$ Ron Dudai \& Kieran McEvoy, 'Thinking Critically About Armed Groups and Human Rights Praxis', Journal of Human Rights Practice, 4, no. 1 (2012): 1 - 29.

${ }^{11}$ Phillip Alston, 'The 'Not-a-Cat' Syndrome: Can the International Human Rights Regime Accommodate NonState Actors?' in Non-State Actors and Human Rights ed. Phillip Alston (Oxford: Oxford University Press, 2005), 3.

${ }^{12}$ For further discussion see Andrew Clapham, Human Rights Obligations of Non-State Actors (Oxford: Oxford University Press, 2006); Henry Steiner, Phillip Alston \& Ryan Goodman, International Human Rights Law in Context: Law, Politics, Morals ( ${ }^{\text {rd }}$ ed) (Oxford: Oxford University Press, 2008); Rhona Smith, International Human Rights Law ( $8^{\text {th }}$ ed.) (Oxford: Oxford University Press, 2018); Jan Hessbruegge, 'Human Rights Violations Arising From Conduct of Non-State Actors', Buffalo Human Rights Law Review 11, (2005): 21 - 88.

${ }^{13}$ Gunter Teubner, 'Global Bukowina' in Global Law Without a State ed. Gunter Teubner (Aldershot: Darthmouth, 1997), 14.

${ }^{14}$ Dudai \& McEvoy, 'Thinking Critically About Armed Groups and Human Rights Praxis'.

${ }^{15}$ Makau Mutua, 'Savages, Victims and Saviours: The Metaphor of Human Rights', Harvard International Law Journal 42, no. 1 (2001): 201

${ }^{16}$ Thorsten Bonacker, 'Global Victimhood: On the Charisma of the Victim in Transitional Justice Processes', World Political Science Review 9, no. 1 (2013): 97 - 129.

${ }^{17}$ Girelli, Understanding Transitional Justice, 26.

18; Susanne Karstedt, 'From Absence to Presence, From Silence to Voice: Victims in International and Transitional Justice Since the Nuremburg Trials', International Review of Victimology 17, no. 1 (2010): 9 - 30.

${ }^{19}$ Jonathan Doak, Victims' Rights, Human Rights and Criminal Justice: Reconceiving the Role of Third Parties (Hart: Oxford, 2008), 8.

${ }^{20}$ Robert Elias, The Politics of Victimisation (Oxford: Oxford University Press, 1986); Rob Mawby \& Sandra Walklate, Critical Victimology: International Perspectives (London: SAGE, 1994).

${ }^{21}$ Paige Arthur, 'How “Transitions" Reshaped Human Rights: A Conceptual History of Transitional Justice', Human Rights Quarterly 31, (2009): 321 - 367.

22 Doak, Victms' Rights, Human Rights and Criminal Justice, 8.

${ }^{23}$ Kieran McEvoy \& Kirsten McConnachie, 'Victimology in Transitional Justice: Victimhood, innocence and hierarchy', European Journal of Criminology 9, no. 5 (2013): 527 - 538.

${ }^{24}$ S Walklate, Victimology: The Victim and the Criminal Justice Process (London: Unwin Hyman, 1989); Randall Kennedy, 'The state, criminal law and racial discrimination: a comment', Harvard Law Review 107, no. 6 (1994): 1255 - 1278; Alan Norrie, Crime, Reason and History: A Critical Introduction to Criminal Law (Cambridge: Cambridge University Press, 2014). 
${ }^{25}$ Elias, The Politics of Victimisation.

${ }^{26}$ William Schabas, 'Victor's Justice: Selecting 'Situations' at the International Criminal Court', The John Marshall Law Review 43, no. 3 (2010): $535-552$.

${ }^{27}$ Timothy McCormack, 'Selective Reaction to Atrocity: War Crimes and the Development of International Criminal Law', Albany Law Review 60, no. 1 (1996): 681 - 733.

${ }^{28}$ Chiseche Mibenge, Sex and International Tribunals: The Erasure of Gender from the War Narrative (Philadelphia: University of Pennsylvania Press, 2013).

29 James Holstein \& Gale Miller, 'Rethinking Victimization: An Interactional Approach to Victimology', Symbolic Interaction 13, no. 1 (1990): $103-122$.

${ }^{30}$ Uwe Ewald, 'Victimization in the Context of War - Some Aspects of a Macro-Victimological Research Project', European Journal of Crime, Criminal Law and Criminal Justice 10, (2002): 90 - 97.

${ }^{31}$ Madlingozi, 'Good Victims, Bad Victims'.

${ }^{32}$ Kevin Hearty, 'Legislating Hierarchies of Victimhood and Perpetrators: The Civil Service (Special Advisers) Act (Northern Ireland) and the Meta-conflict', Social \& Legal Studies 25, no. 3, (2016): 333 - 353.

${ }^{33}$ Kieran McEvoy, Ron Dudai \& Cheryl Lawther, 'Criminology and Transitional Justice' in The Oxford Handbook of Criminology ( $6^{\text {th }}$ ed) eds. Alison Leibling, Shadd Maruna \& Lesley McAra (Oxford: Oxford University Press, 2017), 404.

${ }^{34}$ Erica Bouris, Complex Political Victims (Bloomfield: Kumarian, 2007), 31.

${ }^{35}$ Nils Christie, 'The ideal victim' in From crime policy to victim policy ed. Ezzat Fattah (Hampshire: Palgrave MacMillan, 1986).

${ }^{36}$ Jan van Dijk, 'Free the victim: A critique of the western conception of victimhood' International Review of Victimology 16, no. 1 (2009): 1-33.

37 Trudy Govier \& Wilhelm Verwoerd, 'How not to polarize 'victims' and perpetrators', Peace Review 16, no. 3 (2004): $371-377$.

${ }^{38}$ Illanit Simantov-Nachlieli, Nurit Shnabel \& Samer Halabi, 'Winning the victim status can open conflicting groups to reconciliation: Evidence from the Israeli-Palestinian Conflict', European Journal of Social Psychology 45, (2015): $139-145$.

${ }^{39}$ McEvoy \& McConnachie, 'Victims and Transitional Justice'; Cheryl Lawther, Truth, Denial and Transition: Northern Ireland and the Contested Past (Oxon: Routledge, 2014); Amaia Alvarez-Berastegi, 'Transitional justice in settled democracies: Northern Ireland and the Basque Country in comparative perspective', Critical Studies on Terrorism 10, no. 3 (2017): 542 - 561.

40 Garrath Williams, 'Dangerous Victims: On Some Political Dangers of Vicarious Claims to Victimhood', Distinktion: Journal of Social Theory 9, no. 2 (2008): 77 - 95.

41 Johanna Vollhardt, 'Inclusive Victim Consciousness in Advocacy, Social Movements, and Intergroup Relations: Promises and Pitfalls', Social Issues and Policy Review 9, no. 1 (2015): $89-120$.

42 Juliana Ochs, 'The Politics of Victimhood and its Internal Exegetes: Terror Victims in Israel', History and Anthropology 17, no. 4 (2006): $355-368$.

${ }^{43}$ Alvarez-Berastegi, 'Transitional justice in settled democracies'.

${ }^{44}$ Tazreena Sajjad, 'Heavy Hands, Helping Hands, Holding Hands: The Politics of Exclusion in Victims' Networks in Nepal', International Journal of Transitional Justice 10, (2016): 25 - 45.

45 Ochs, 'The Politics of Victimhood and its Internal Exegetes'.

${ }^{46}$ John Brewer, Peace Processes: A Sociological Approach (Cambridge: Polity Press, 2010).

${ }^{47}$ HAVEN, In search of a Haven (Newtownabbey: Island, 2002), 3.

${ }^{48}$ John Nagle, 'The Ulster Unionist victims' movement: political opportunities and injustice masterframes', Irish Journal of Sociology 17, no. 1 (2009): $19-37$.

${ }^{49}$ Lawther, Truth, Denial and Transition.

${ }^{50}$ Nevin Aiken, Identity, reconciliation and transitional justice: Overcoming intractability in divided societies, (Oxon: Routledge, 2013). 
${ }^{51}$ Marcel Baumann, 'Understanding the Other's 'Understanding' of Violence: Legitimacy, Recognition, and the Challenge of Dealing with the Past in Divided Societies', International Journal of Conflict and Violence 3, no. 1 (2009): 107- 123.

${ }^{52}$ Homes United by Ruthless Terror (HURT), The forgotten victims (Newtownabbey: Island, 2001), 21.

${ }^{53}$ Jessie Hronesova, 'Might Makes Right: War-Related Payments in Bosnia and Herzegovina', Journal of Intervention and Statebuilding 10, no. 3 (2016): 339 - 360.

${ }^{54}$ Nagle, 'The Ulster Unionist victims' movement'.

${ }^{55}$ Alan McBride, 'Hierarchy of victims: A question of hierarchy', WAVE Newsletter, February 2009.

56 Damian McCarney, 'Belfast's forgotten Bloody Sunday', Andersonstown News, 6 August 2007.

${ }^{57}$ Alvarez-Berastegi, 'Transitional justice in settled democracies'.

${ }^{58}$ Jemima Garcia-Godos \& Knut Lid 'Transitional Justice and Victims' Rights before the End of a Conflict: The Unusual Case of Columbia' Journal of Latin American Studies 42, (2010): 487-516.

${ }^{59}$ Pablo De Greiff, 'Report of the Special Rapporteur on the promotion of truth, justice, reparation and guarantees of non-recurrence, on his mission to the United Kingdom of Great Britain and Northern Ireland', The Office of the United Nations High Commissioner for Human Rights (17 November 2016), 14, www.ohchr.org/Documents/Issues/.../A_HRC_34_62_Add_1_en.docx (accessed February 16, 2017). ${ }^{60}$ 'Fermanagh victims speak at new Charter launch at Stormont', Impartial Reporter, 25 April 2013, http://www.impartialreporter.com/news/13862342.Fermanagh victims speak at new Charter launch at S tormont/ (accessed October 25, 2017).

${ }^{61}$ Hearty, 'Legislating Hierarchies of Victimhood and Perpetrators'.

$62 \mathrm{lbid}$

${ }^{63}$ Padraig McAuliffe, Transformative Transitional Justice and the Malleability of Post-Conflict States (Cheltenham: Edward Elgar, 2017).

${ }^{64}$ Ruti Teitel, 'Transitional Justice Genealogy', Harvard Human Rights Journal 16, (2003): 69 - 94.

${ }^{65}$ Hessbruegge, 'Human Rights Violations Arising From Conduct of Non-State Actors'.

${ }^{66}$ Rob Watts, States of Violence and the Civilising Process: On Criminology and State Crime (London: Palgrave MacMillan, 2016).

${ }^{67}$ Kay Schaffer \& Sidonie Smith, Human Rights and Narrated Lives: The ethics of recognition (Hampshire:

Palgrave MacMillan, 2004).

${ }^{68}$ Steffen Jensena et al, 'Torture and III-treatment Under Perceived: Human Rights Documentation and the Poor', Human Rights Quarterly 39, no. 2, (2017): $394-415$.

${ }^{69}$ HAVEN, In search of a haven, 5.

${ }^{70}$ Mijke de Waardt, 'Are Peruvian Victims Being Mocked?: Politicisation of Victimhood and Victims' Motivations for Reparations', Human Rights Quarterly 35, no. 4 (2013): 830 - 849.

${ }^{71}$ Mijke de Waardt, 'Naming and Shaming Victims: The Semantics of Victimhood', International Journal of Transitional Justice 10, (2016): $432-450$.

72 'Victims and Relatives Canvass for War Crimes Reparations Law in El Salvador', Telesur, 1 September 2017, https://www.telesurtv.net/english/news/Victims-and-Relatives-Canvass-for-War-Crimes-Reparations-Law-inEl-Salvador-20170901-0018.html (accessed September 7, 2017).

${ }^{73}$ Luke Moffett, A pension for injured victims of the Troubles: reparations or reifying victim hierarchy?', Northern Ireland Legal Quarterly 66, no. 4 (2016): 297-319.

${ }^{74}$ Erika De Wet \& Jure Vidmar (eds), Hierarchy in international law: the place of human rights (Oxford: Oxford University Press, 2012); Eckart Klein, 'Establishing a hierarchy of human rights: Ideal solution or fallacy?', Israel Law Review 41, no. 3 (2008): 477 - 488; Theodor Meron, 'On a hierarchy of international human rights', American Journal of International Law 80, no. 1, (1986): 1 - 23.

${ }^{75}$ Robert Hoag, 'International Covenant on Civil and Political Rights' in Encyclopaedia of Global Justice ed. D Chatterjee (Dordrecht: Springer, 2011).

${ }^{76}$ Diane Orentlicher, 'Settling Accounts: The Duty to Prosecute Human Rights Violations of a Prior Regime', The Yale Law Journal 100, no. 8 (1991): $2537-2615$.

${ }_{77}$ McEvoy, Dudai \& Lawther, 'Criminology and Transitional Justice', 396.

${ }^{78}$ Colm Campbell and Catherine Turner, 'Utopia and the doubters: Truth, Transition and the Law', Legal Studies 28, no. 3 (2008): $374-395$. 
79 Rivas, 'Official Victims' Registries'.

${ }^{80}$ Hronesova, 'Might Makes Right'.

81 Lauren Dempster, 'The Republican Movement, 'Disappearing', and Framing the Past in Northern Ireland', International Journal of Transitional Justice 10, no. 2 (2016): 250-271.

82 Ibid.

83 Sajjad, 'Heavy Hands, Helping Hands, Holding Hands'.

84 Luke Moffett, 'Transitional Justice and Reparations: Remedying the Past?', SSRN, (2015) [Online]. Available at: https://papers.ssrn.com/sol3/papers.cfm?abstract_id=2564520 (Accessed: 1 September 2017).

${ }^{85}$ Eilish Rooney, Transitional Justice Grassroots ToolKit: User's Guide (Bridge of Hope: Belfast, 2016), 35.

${ }^{86}$ Martha Minow, Breaking the Cycles of Hatred: Memory, Law, and Repair. (New Jersey: Princeton University Press, 2002).

${ }^{87}$ Rooney, Transitional Justice Grassroots Toolkit, 35.

${ }^{88}$ Hugo Van der Merwe, 'Reparations through different lenses: The culture, rights and politics of healing and empowerment after mass atrocities', in Reparations for Victims of Crimes against Humanity: The healing role of reparation ed. Joanne.M Wemmers (Oxon: Routledge, 2014), 204.

89 Jon Elster, Closing the books: Transitional Justice in Historical Perspective (Cambridge: Cambridge University Press, 2004), 176.

90 Andrieu, 'Confronting the Dictatorial Past in Tunisia'.

${ }^{91}$ Priscilla Hayner, Unspeakable Truths: Transitional Justice and the Challenge of Truth Commissions ( $2^{\text {nd }}$ ed.) (New York: Routledge, 2011).

92 Katherine Franke, 'Gendered Subjects of Transitional Justice', Columbia Journal of Gender and Law 15, no. 3 (2006): $813-828$.

93 McEvoy, Dudai \& Lawther, 'Criminology and Transitional Justice', 403.

${ }^{94}$ Farren Collins, 'R1.5 billion for apartheid victims but thousands still waiting for money', Sunday Times, 28 August 2017, https://www.timeslive.co.za/politics/2017-08-28-r15-billion-for-apartheid-victims-butthousands-still-waiting-for-money/ (accessed September 7, 2017).

95 Borer, 'A Taxonomy of Victims and Perpetrators'.

96 Ibid.

${ }^{97}$ Collins, 'R1.5 billion for apartheid victims but thousands still waiting for money'.

98 Ibid.

${ }^{99}$ Christopher Colvin, 'Overview of the Reparations Program in South Africa', in The Handbook of Reparations ed. Pablo De Greiff (New York: Oxford University Press, 2006), 189.

100 Louise Chappell, 'The gender injustice cascade: 'transformative' reparations for victims of sexual and genderbased crimes in the Lubanga case at the International Criminal Court', The International Journal of Human Rights 21, no. 9 (2017): 1223- 1242.

101 Girelli, Understanding Transitional Justice, 17.

102 Franke, 'Gendered Subjects of Transitional Justice'. 103 Ibid.

104 Fionnuala Ni Aolain \& Catherine Turner, 'Gender, truth and transition', UCLA Women's Law Journal 16, (2007): $229-279$.

${ }^{105}$ Emily Wright, 'Guerilla baby boom as FARC rebels lift 50 year pregnancy ban', Women's Media Centre, 25 July 2017, http://www.womensmediacenter.com/women-under-siege/guerilla-baby-boom-as-farc-rebels-lift-50year-pregnancy-ban (accessed September 7, 2017).

${ }^{106}$ Sara Davies and Jacqui True, 'When there is no justice: gendered violence and harm in post-conflict Sri Lanka', The International Journal of Human Rights 21, no. 9 (2017): 1320 - 1336.

107 Hing Socheata and Meng Neradey, 'Khmer Rouge-era Rape Cases Remain Taboo Topic, Justice Elusive for Survivors', Voice of Asia, 3 September 2017, accessed online via https://www.voanews.com/a/cambodia-khmerrouge-era-rape-justice-elusive/4013114.html accesed 07/09/2017 at 20:08

108 Jamesina King, 'Gender and reparations in Sierra Leone: the wounds of war remain open' in What happened to the women? Gender and reparations for human rights violations ed. Ruth Rubio-Marin (New York: Social Sciences Research Council, 2006). 
109 Hronesova, 'Might Makes Right'.

110 Janine Clark, 'Transitional Justice as Recognition: An Analysis of the Women's Court in Sarajevo', International Journal of Transitional Justice 10, no. 1 (2016): 67 - 87.

111 Ibid.

112 Hans Von Hentig, The criminal \& his victim (Connecticut: Yale University Press, 1948).

113 Benjamin Mendelsohn, 'Victimology and contemporary society's trends', Victimology: An International Journal 1, no. 1 (1976): 8 -28.

${ }^{114}$ Borer, 'A Taxonomy of Victims and Perpetrators'.

115 Ignacio Fernandez de Mata, 'From Invisibility to Power: Spanish Victims and the Manipulation of their Symbolic Capital', Totalitarian Movements and Political Religions 9, no. 20 (2008): 253 - 264.

${ }^{116}$ Naomi Cahn, 'Beyond Retribution and Impunity: Responding to War Crimes of Sexual Violence', Stan. JCR \& CL 1 (2005): 217.

${ }^{117}$ Franke, 'Gendered Subjects of Transitional Justice'.

118 Chappell, 'The gender injustice cascade'.

${ }^{119}$ Diana Contreras-Garduno \& Julie Fraser, 'The identification of victims before the Inter-American Court of Human Rights and the International Criminal Court and its impact on participation and reparation: a domino effect', Inter-American \& European Human Rights Journal 7, (2014): 174 - 203.

120 Ibid.

${ }^{121}$ Bouris, Complex Political Victims, 84.

122 McEvoy \& McConnachie, 'Victims and Transitional Justice'.

123 Bouris, Complex Political Victims, 75.

${ }^{124}$ Pete Shirlow \& Kieran McEvoy, Beyond the wire: Former prisoners and conflict transformation in Northern Ireland (London: Pluto, 2008); Pete Shirlow et al., Abandoning Historical Conflict? Former Political Prisoners and Reconciliation in Northern Ireland (Manchester: Manchester University Press, 2010).

${ }^{125}$ Luke Moffett, 'Reparations for 'Guilty Victims': Navigating Complex Identities of Victim-Perpetrators in Reparation Mechanisms', International Journal of Transitional Justice 10, no. 1 (2015): 146 - 167.

${ }^{126}$ Ruth Jamieson, 'Framing Blame and Victimhood in Post-Conflict Northern Ireland', in The Palgrave Handbook of Criminology and War eds. Ross McGarry \& Sandra Walklate (Hampshire: Palgrave, 2016).

${ }^{127}$ Cheryl Lawther, 'The Truth about Loyalty: Emotions, Ex-Combatants and Transitioning from the Past', International Journal of Transitional Justice 11, no 3 (2017): 484 - 504.

128 McBride, 'Hierarchy of victims'.

129 Borer, 'A Taxonomy of Victims and Perpetrators'.

130 Mark Drumbl, Reimagining Child Soldiers in International Law and Policy (Oxford: Oxford University Press, 2012).

131 Ibid.

132 Mark Drumbl, 'Victims who victimise', London Review of International Law 4, no. 2 (2016): 217 - 246.

133 Rooney, Transitional Justice Grassroots Toolkit, 35.

${ }^{134}$ Richard Bowd \& Alpaslan Ozerdem, 'How to Assess Social Reintegration of Ex-Combatants', Journal of Intervention and Statebuilding 7, no. 4 (2013): $453-475$.

135 Donna Seto, 'Children born of wartime sexual violence and the limits of existence', Peacebuilding 3, no. 2 (2015),: $171-185$.

136 Joanne Neenan, 'The Role of the ICC in Protecting the Rights of Children Born of Rape in War', EJIL Talk, 12 February 2018, < https://www.ejiltalk.org/the-role-of-the-icc-in-protecting-the-rights-of-children-born-ofrape-in-war/> (accessed February 20, 2018).

${ }^{137}$ Eithne Dowds, 'Children Born of Rape in Bemba: Can the ICC Close the Accountability Gap?', INTLAWGIRLS, 16 January 2018, https://ilg2.org/2018/01/16/children-born-of-rape-in-bemba-can-the-icc-close-theaccountability-gap/ (accessed February 21, 2018).

138 Eva de Vries, 'Born of rape', DW, 8 August 2017, http://www.dw.com/en/born-of-rape/a-40013755 (accessed September 7, 2017).

139 Ibid. 
${ }^{140}$ Apophia Agiresaasi, 'Children of Uganda's Civil War face lingering stigma', The Seattle Globalist, 23 August 2017, http://www.seattleglobalist.com/2017/08/23/children-uganda-civil-war-update/68292 (accessed 7 September, 2017).

${ }^{141}$ Ibid.

${ }^{142}$ Neenan, 'The Role of the ICC in Protecting the Rights of Children Born of Rape in War'.

$143 \mathrm{lbid}$.

${ }^{144}$ Ibid.

${ }^{145}$ Dowds, 'Children Born of Rape in Bemba'.

${ }^{146}$ Chandra Lekha Sriram \& Johanna Herman, 'DDR and transitional justice: bridging the divide?', Conflict, Security \& Development 9, no. 4 (2009): $455-474$.

${ }^{147}$ Davies \& True, 'When there is no justice'.

148 Ibid.

149 Jaremey McMullin, Ex-combatants and the Post-conflict State: Challenges of Reintegration (New York: Springer, 2013).

${ }^{150}$ Shirlow \& McEvoy, Beyond the wire; Jamieson, 'Framing Blame and Victimhood in Post-conflict Northern Ireland'; Shirlow et al., Abandoning Historical Conflict?; Grainne McKeever, 'Citizenship and social exclusion: The re-integration of political ex-prisoners in Northern Ireland', British Journal of Criminology 47, no. 3 (2007): 423 - 438; Bill Rolston, 'Demobilization and reintegration of ex-combatants: The Irish case in international perspective', Social \& Legal Studies 16, no. 2 (2007): $259-280$.

151 Jemima Garcia-Godos \& Chandra Lekha Sriram, 'Introduction', in Transitional Justice and Peacebuilding on the Ground: Victims and Ex-Combatants eds. Chandra Lekha Sriram et al., (Oxon: Routledge 2013); McMullin, Ex-combatants and the Post-Conflict State.

152 Jamieson, 'Framing Blame and Victimhood in Post-Conflict Northern Ireland'.

153 Kees Kingma, 'Demobilisation and peacebuilding in Africa' in Recovering from civil conflict: reconciliation, peace and development eds. Edward Newman \& Albert Schnabel (London: Frank Cass, 2002).

${ }^{154}$ Hearty, 'Legislating Hierarchies of Victimhood and Perpetrators'.

${ }^{155}$ McEvoy \& McConnachie, 'Victims and Transitional Justice'.

${ }^{156}$ Ismael Muvingi, 'Sitting on powder kegs: Socioeconomic rights in transitional societies', International Journal of Transitional Justice 3, no. 2, (2009): 163 - 182; Elisabeth Wickeri, 'No Peace, No Justice: Conflict, Socio-economic Rights and the New Constitution in Nepal, Drexel Law Review 2 (2009): 427; Eilish Rooney, 'Engendering transitional justice: Questions of absence and silence', International Journal of Law in Context 3, no. 2 (2007): $173-187$.

${ }^{157}$ Hearty, 'Legislating Hierarchies of Victimhood and Perpetrators'. 